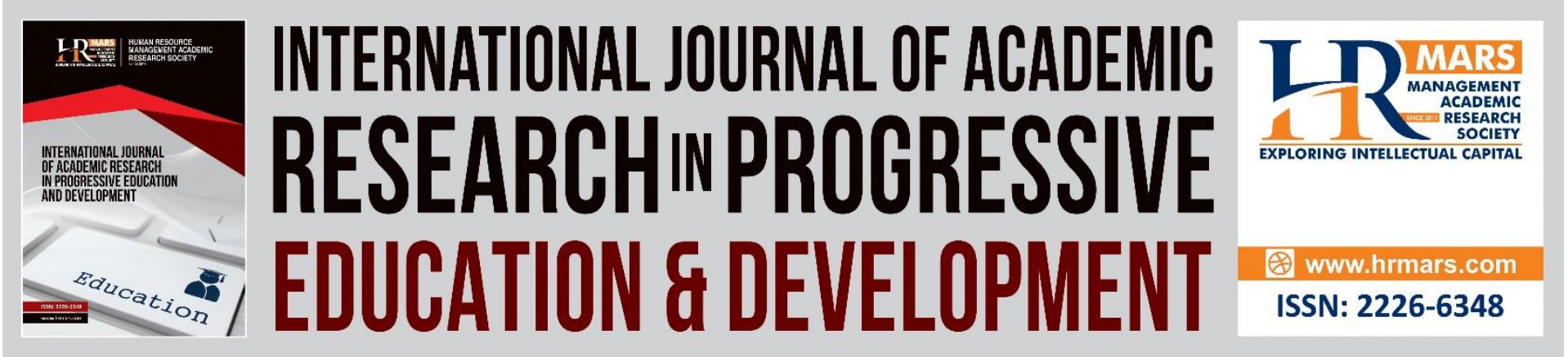

\title{
Collaborative Writing Strategies: The Effects on Malaysia Secondary School Learners' Writing Fluency
}

\section{Muhammad Nafis Bin Azman, Mohamad Kamal Bin Ayub}

To Link this Article: http://dx.doi.org/10.6007/IJARPED/v10-i2/10595

DOI:10.6007/IJARPED/v10-i2/10595

Received: 17 May 2021, Revised: 22 June 2021, Accepted: 11 July 2021

Published Online: 28 July 2021

In-Text Citation: (Azman \& Ayub, 2021)

To Cite this Article: Azman, M. N. Bin, \& Ayub, M. K. Bin. (2021). Collaborative Writing Strategies: The Effects on Malaysia Secondary School Learners' Writing Fluency. International Journal of Academic Research in Progressive Education and Development, 10(2), 1051-1064.

Copyright: (C) 2021 The Author(s)

Published by Human Resource Management Academic Research Society (www.hrmars.com)

This article is published under the Creative Commons Attribution (CC BY 4.0) license. Anyone may reproduce, distribute, translate and create derivative works of this article (for both commercial and non-commercial purposes), subject to full attribution to the original publication and authors. The full terms of this license may be seen at: http://creativecommons.org/licences/by/4.0/legalcode

Vol. 10(2) 2021, Pg. 1051 - 1064

http://hrmars.com/index.php/pages/detail/IJARPED

JOURNAL HOMEPAGE

Full Terms \& Conditions of access and use can be found at http://hrmars.com/index.php/pages/detail/publication-ethics 


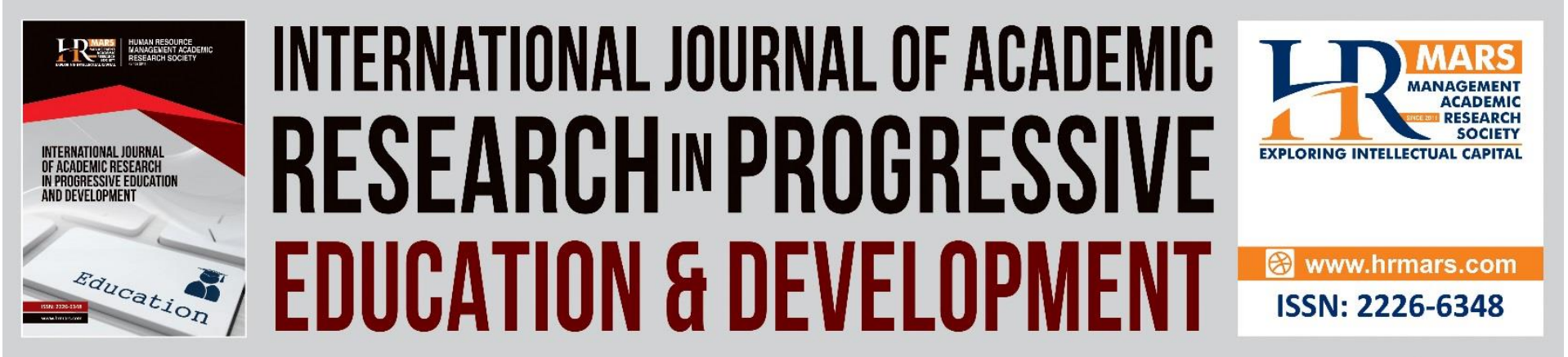

\title{
Collaborative Writing Strategies: The Effects on Malaysia Secondary School Learners' Writing Fluency
}

\author{
Muhammad Nafis Bin Azman \\ English Teacher, SMK Dato Abdul Rahman Andak, Kluang, Malaysia \\ Email: muhammadnafisazman@yahoo.com \\ Mohamad Kamal Bin Ayub \\ English Teacher, SMK Megat Dewa \\ Email:mohammadkamalayub@gmail.com
}

\begin{abstract}
This study aimed to find out the effects of collaborative writing strategies on ESL learners' writing fluency which specifically focused on content elaboration and organization in the essays. This qualitative study employed an action research design and the participants were twenty form four pupils (age 16) from one of the secondary schools in Kluang, Johor. The participants underwent sequential and parallel collaborative writing strategies throughout 12 lessons which revolved around 6 weeks after their first writing task. They sat for their final writing tasks after 6 -week of the implementation of collaborative writing strategies. After 6 weeks of 12 lessons the participants sat for their final writing task which had the same question. The analysis of the first and final writing task was used to find out the effects of collaborative writing strategies on the elaboration of contents and organization of their writing. The finding revealed that learners showed moderate or significant changes on the elaboration of contents and organization in their final writing. Therefore, collaborative writing strategies could be one of the timeless and feasible strategies that teachers can put into practice in enhancing $21^{\text {st }}$ century learners' writing fluency.
\end{abstract}

Keywords: Collaborative, ESL, Writing Fluency, Writing Skills, Writing

\section{Introduction}

English writing is one of productive and communicative language skills which has a crucial role in international communication. Writing is used to transfer and deliver information from one to another and English is internationally used as the main medium. Writing requires learners to be rhetorically and linguistically competent (Ghufron \& Hawa, 2018). Furthermore, learners also need to have knowledge of the topics they want to write and also the confidence to write. The ability to generate ideas, organise the essays and write 
fluently is crucial in order to produce a quality piece of writing. Hence, it is vital for teachers to enhance learners' fluency writing skills by using feasible writing strategies. However, are learners given the rooms to interact and express their ideas and opinions? The problem of poor grasp to writing skills among ESL learners is led by one of contributing factors which is low writing motivation because of the perception learners have towards writing (Ismail et al., 2012). One of the difficulties faced by Malaysian learners is the ability to organize their ideas in their essays and it also involves presenting their ideas logically, coherently and clearly. Lim, Yunus and Mohamed (2018) bring up the issue that learners are not motivated to write because of an unconducive environment especially in rural areas and learners are highly relied on by the teachers to complete the task. Lo and Hyland (2007) highlights the importance of making language activities or tasks which offer them social interaction and self-expression. So, teachers are responsible to provide learners with that kind of environment and enhance their interest to write

Thus, the use of collaborative writing strategies is proposed in this study as one of the feasible ways to enhance learners' writing. Collaborative writing strategies allow social interaction and provide learners a conducive and less-threatening environment. Collaborative writing strategies shift away from a teacher-centered environment which is dry to a learnercentered classroom which is interactive (Shafie et al., 2010). Therefore, this study measured the effects of collaborative writing on length of writing text, elaboration of contents and organisation of the essay. Also, this study enlightened the teachers, especially English teachers on how collaborative writing will help them to ensure the three components of writing fluency before they start improving on the technical parts of their writing.

\section{Writing in ESL Classroom}

Writing is one of the most important skills in language learning. It is a process of transmitting thoughts and ideas to paper and it requires learners to express meanings by using words (Ghufron \& Hawa, 2018). It is one of the difficult skills even in terms of first language learning. Most ESL learners have issues with psychological problems and linguistic problems (Ghufron \& Hawa, 2018). While writing skill is regarded as critical and essential for ESL learners, it is the most difficult skill as it requires learners to master many cognitive and linguistic strategies (len et al., 2018). Due to these factors learners show lack of motivation in either learning to write or doing writing tasks.

Lim, Yunus and Mohamed (2018) claim that many Malaysian learners are passive learners who have lack of vocabulary and difficulty to generate ideas which leads to anxiety and uncertainty. They encourage teachers to allow learners to take ownership of their own learning as well as create social interaction although for teaching writing. In addition, it is important that writing tasks should not be viewed as an individual task especially to ESL learners as it leads to low intrinsic motivation, prejudice, and anxiety (Aminloo, 2013). Collaborative writing can provide a platform for proficient learners to help less proficient learners and therefore reduce their anxiety and might boost their motivation.

\section{What is Collaborative Writing?}

Collaborative writing is one the approaches that can be used to teach and learn writing. It is defined as a "social process" which encourages writers who have the same focus, a common goal and it opens a room for them to communicate, negotiate and coordinate the ideas and writing content (Roselli, 2016). Kwon (2014) states that collaborative work involves 
learner-learner interaction where learners have the authority over their learning and are socially engaged in collaborative learning. Collaborative writing is one method to move writing from a solitary act to a social act involving peer interaction (Stell, 2018) and has proven its effectiveness in language learning and teaching (Al Ajmi \& Ali, 2014). Collaborative writing is closely related to sociocultural theory by the pioneer Vygostsky who discovered social contexts as one of the roots for the learning and communication process (Kwan \& Yunus, 2015). Vygotsky came up with the idea of collaborative writing and he proposed that collaborative writing encourages learners to contribute ideas for their own learning and growth. This provides learners the chance to learn from their peers making the learning more meaningful.

\section{The Effects of Collaborative Writing}

Studies on collaborative writing have shown that it has many positive impacts on both motivation and writing fluency. Ghufron (2018) found out that both motivation and writing quality are improved with collaborative writing. Collaborative writing shapes learners to take ownership and be responsible for their own learning as learners should contribute to the completion of their group's writing task (Fong, 2012). As a result, he points out that learners became more committed in completing their writing. In a study conducted by Khodabakhshzadeh and Samadi (2017), most participants found collaborative writing was very effective as it enhanced their motivation. Jalili and Shahrokhi (2017) also found that collaborative groups had significantly lower writing anxiety rates than the individual group. This reflects that the learners' motivation is enhanced with collaborative writing sessions. Another positive impact of collaborative writing is the writing quality improvement as it helps learners to improve their writing fluency which can be defined as well-organised, the appropriate use of words, and clarity of the texts with neat expression of ideas, harmony and coherence (Atasoy \& Temizkan, 2016). Participants showed improvement on organization (Islam and Maab, 2012) and was able to link and sequence their ideas, sentences and paragraphs well (Aminloo, 2013). Furthermore, it is found out that collaborative writing strategies helped learners to pool ideas and extend their texts longer (Shehadeh, 2011 and Zhang, 2018). This is as they were able to produce and develop a wide range of ideas from their brainstorming sessions or group discussion (Aminloo, 2013). A fluent writer should also be able to produce the highest number of word counts in an allocated time (Jalili \& Shahrokhi, 2017 and Pae, 2011). Fellner, Apple, Faculty, \& Dormer (2006) state Brown (1994) also supports the idea that one of the components in writing fluency is word counts. Collaborative writing strategies improve the length of the learners' writing (Jalili \& Shahrokhi, 2017) as during collaborative sessions, learners are able to gain new information (Shehadeh, 2011) and also acquire new vocabulary (Wahjusaputri, 2016).

With collaborative writing sessions, learners will be able to compensate for their weaknesses in motivation and writing fluency. This is as they reduce their anxiety and can learn from their partners who have better command in the language. These studies have helped give insights on how collaborative writing can bring a positive impact on learners' writing fluency. It helps learners to solve writing problems such as lack of words count, elaborating contents and organizing technique. This current study was carried out in a secondary school. This study would also focus on how collaborative writing strategies might enhance three components of writing which are word counts or length of the text, content elaboration and organization of the essay. 
DEVELOPMENT

Vol. 10, No. 2, 2021, E-ISSN: 2226-6348 @ 2021 HRMARS

\section{The Strategies of Collaborative Writing}

There are a few types of collaborative writing. According to Marshan (2016), collaborative writing tasks should demand students to utilise the skills that improve their accountability, cooperation and community. These elements should help them to achieve the objectives or goals of the tasks. Marsha (2016) also mentions that collaborative writing strategies result in a quality production of good composition through their cooperation with peers. There are five strategies listed by Marsha (2016) which are group single- author writing, sequential single writing, parallel writing, reactive writing and mixed-mode. The group single-author writing strategy is when only one member is involved in writing up the product but during the planning, drafting and reviewing process, all members of the team contribute and work towards coordinated decision or consensus of the written product. In contrast, the sequential single writing strategy requires every member to write a portion of the written document. They start with a brainstorming session and move on to taking turns in writing their parts and passing the draft to other members to continue writing their respective parts. The third strategy, parallel writing is when each member is assigned to work on a different part of the document at the same time (horizontal division parallel writing) or each member is assigned to a different role such as authors, editors and facilitators (stratified division parallel writing). Another strategy is reactive writing strategy that involves all group members to work on every part of the document synchronously. They draft, edit and review every part of the document together. Lastly, mixed mode is the strategy which combines two or more collaborative writing strategies. This strategy is very flexible as teachers can try and error on which strategy/strategies suit their learners' proficiency or preferences. Marshan (2016) reminds teachers to give careful consideration before choosing the right collaborative strategies. Each strategy has its own advantages and disadvantages which might give impacts on the learning process.

\section{Research Design}

Jean McNiff's Model of action research design was adapted and it will involve four cycles which are: planning, acting, observing and reflecting. This study employed an action research design because the researcher (as a teacher) was allowed to observe whether collaborative writing strategies had brought any positive effects on word counts, elaboration of the contents and organisation of the writing. The researcher was using action research to enhance writing instruction to improve learners' writing.

\section{Participants}

Convenience sampling is adapted for this study because the researcher had access to 20 students of a form 4 class (age 16) in the population. The samples of this study were chosen because they had the same ability when it came to the proficiency of English language. Their level of English command was determined by their mid-term examination essay section B question which all of them scored band $E$ and below for their writing. According to the marking rubric prepared by Malaysian Examination Syndicate, band E and below shows incompetency in terms of number of words, contents and poor organization in writing. All of the participants fall into the intermediate level of English command. This action research was carried out for 6 weeks and it was equal to 12 sessions. 
DEVELOPMENT

Vol. 10, No. 2, 2021, E-ISSN: 2226-6348 @ 2021 HRMARS

\section{Research Procedure}

Initially, participants completed the first writing task which required them to write a 350-word descriptive essay. Then, the collaborative writing strategies were done for 6 weeks and these participants would undergo writing collaboratively in 12 writing lessons. During the lessons, participants were divided into 4 groups and these groups remained until they completed all 12 lessons. Each group was tasked with a writing task and it must be completed within 2 lessons. Every lesson involved a few writing processes which were delegation of the task, brainstorming, drafting, peer checking and final writing. Mixed-mode collaborative writing strategy was used because teachers can try and error on which strategy/strategies suit their learners' proficiency or preferences. After the collaborative writing lessons were completed, the participants were tasked with their final writing task. Both, first and last writing task consisted of the same essay question in which they had to write a 350-word length of a descriptive essay.

\section{Data Collection and Analysis}

First and final writing tasks were used as the main instruments to investigate the effects of collaborative writing strategies on learners' writing fluency. Comparison between their first and final writing tasks were made. There were two criteria which were looked into; content elaboration and organization of the writing. These criteria were important for the participants to score good marks in their English Paper 1. The extracts from their writing were included in the data analysis to give pictures of recurring patterns in their writing.

\section{Result}

\section{Elaboration of the Content}

The data extracted from the participants' essays also revealed how the participants can develop the contents and ideas in their writing. For the first writing, participants (except Participant 10) were limited in terms of idea and content development. Most of the participants tend to conclude their essay on their second paragraph. Their contents were not well developed and it was really difficult for them to brainstorm and generate ideas based on the question. However, after the implementation of collaborative writing strategies, every participant developed their essay into at least five paragraphs and each idea was very well expended and elaborated. For example, when they described a situation, it was described very detailed and organised. Table 1 and 2 show some comparison of the paragraphs before and after the implementation of collaborative writing strategies: 
Table 1. Significant Changes Comparison

\begin{tabular}{|c|c|}
\hline \multicolumn{2}{|l|}{ Significant Changes } \\
\hline First Writing & Final Writing \\
\hline $\begin{array}{l}\text { Last week my friend Zaki was harassed } \\
\text { by senior student. He punched and took } \\
\text { his money. }\end{array}$ & $\begin{array}{l}\text { I have a friend who is often bullied. He is called as } \\
\text { Farhan. He was constantly threatened to finish } \\
\text { everyone's homework and his money was taken } \\
\text { away. He obeyed the orders of the bully for the fear } \\
\text { of getting beaten. Every day at school, he would be } \\
\text { bullied in the toilet... }\end{array}$ \\
\hline $\begin{array}{l}\text { Conclusion: } \\
\text { I told the teacher about the bullying. I } \\
\text { also hugged John to give him some } \\
\text { supports. }\end{array}$ & $\begin{array}{l}\text { Conclusion: } \\
\text { Mary succeeded to solver her problem with my help. } \\
\text { However, there are many bullying cases which are } \\
\text { ignored by the society. I hope my friend can stand up } \\
\text { for the victims. I also keep my fingers crossed for } \\
\text { parents to take care of their children and always give } \\
\text { support to them. The society should also...... }\end{array}$ \\
\hline $\begin{array}{l}\text { Last month, my friend, Daniel was } \\
\text { bullied at the canteen after recess time. } \\
\text { My friend was bullied by older students } \\
\text { as they extorted money from my friend. }\end{array}$ & $\begin{array}{l}\text { Her name was Alice and she came from a poor family. } \\
\text { She was dead and mute. She used the hearing aid to } \\
\text { communicate with her friends. In school, she was a } \\
\text { soft but lonely girl and she always walked alone to the } \\
\text { canteen. When she was in the class, she used the } \\
\text { hearing aid to listen to the teachers. It was very } \\
\text { difficult for her because... }\end{array}$ \\
\hline $\begin{array}{l}\text { Wendy had told me after coming back } \\
\text { home. We had accompanied Wendy to } \\
\text { go back home. After a few days, I waited } \\
\text { Wendy at the back. }\end{array}$ & $\begin{array}{l}\text { Finally, on the second day, our teacher brought the } \\
\text { police to school to find the bullies and they were } \\
\text { brought to the police station. Our school counsellor } \\
\text { also gave counselling sessions to Roy. After a few } \\
\text { days, Roy became more and he was also braver to } \\
\text { face other people. He never allows other to bully him } \\
\text { anymore. }\end{array}$ \\
\hline $\begin{array}{l}\text { In conclusion, I hope nobody in school } \\
\text { will becomes the bully. If they still bully, } \\
\text { they should get a suitable punishment } \\
\text { and I will help anyone who is bullied in } \\
\text { my school. }\end{array}$ & $\begin{array}{l}\text { Finally, after the change that she has on herself, no } \\
\text { one dares to bully her again. She got many friends } \\
\text { and became closer to me. She realised she will not get } \\
\text { bullied if she is brave. I hope after this case, there will } \\
\text { be no bullying problem in my school. I learn that I } \\
\text { need to choose a good friend and a friend who will } \\
\text { help me when I need them. The society also needs to } \\
\text { spread about the negative impacts of bully. I hope } \\
\text { Alice will be happy with her new life and she will also } \\
\text { help other bullying victims in the future. }\end{array}$ \\
\hline
\end{tabular}


DEVELOPMENT

Vol. 10, No. 2, 2021, E-ISSN: 2226-6348 @ 2021 HRMARS

\begin{tabular}{|c|c|}
\hline No conclusion & $\begin{array}{l}\text { Finally, as the conclusion as good friends, we must } \\
\text { stop bullying but helping each other. Bully cannot be } \\
\text { fought alone. Next, the society should spread about } \\
\text { the impact of bullying in school. Parents must also } \\
\text { need to take care of their children condition in school. } \\
\text { After all, everyone must work together to overcome } \\
\text { this bully issue. }\end{array}$ \\
\hline No Paragraph 3 and 4 & $\begin{array}{l}\text { Last week, I saw her being bullied by a group of mean } \\
\text { girls in the toilet. A group of mean girls poured a } \\
\text { gallon of water to Alisa and she was alone in the } \\
\text { toilet. She had to give all of her pocket money to the } \\
\text { bullies. Also, our teachers always scolded her } \\
\text { because she did not do her homework. }\end{array}$ \\
\hline No paragraph 4 & $\begin{array}{l}\text { Last week, Ayu was alone in the class during the } \\
\text { recess time. Suddenly, a group of bullies came to her. } \\
\text { They took Ayu's bag and threw it in the back of the } \\
\text { class. At that time, I was not in the class. When I came } \\
\text { to her, I saw she was crying. I asked her why and she } \\
\text { said all of her things in the bag was missing. She also } \\
\text { said that she could not buy books because.... }\end{array}$ \\
\hline No conclusion & $\begin{array}{l}\text { In conclusion, everyone should play the role to } \\
\text { prevent this issue from happening again. Schools can } \\
\text { create an anti-bullying campaign and parents also } \\
\text { need to control their children to avoid them from } \\
\text { bullying others. This will make school safe and } \\
\text { students will feel comfortable learning in school. }\end{array}$ \\
\hline $\begin{array}{l}\text { One day, I saw Ying sat alone in the } \\
\text { classroom during recess with a lot of } \\
\text { exercise books. I guessed, she was } \\
\text { forced to help those seniors to complete } \\
\text { their homework. } \\
\text { (This participant only wrote } 2 \\
\text { paragraphs and this is the second } \\
\text { paragraph) }\end{array}$ & $\begin{array}{l}\text { Kelly was a very beautiful girl. She had a good look. } \\
\text { She was pretty good in academic despites her hard } \\
\text { life. Although Kelly stayed in a good class, she treated } \\
\text { others kindly. Kelly came from a poor family. It could } \\
\text { be the reason why she could be very attractive. } \\
\text { However, a gang of girls were jealous of Kelly. They } \\
\text { were well known for their bullying behaviour in } \\
\text { school. They already set a plan to bully Kelly. }\end{array}$ \\
\hline
\end{tabular}


Table 2. Moderate Changes Comparison.

\begin{tabular}{|c|c|}
\hline \multicolumn{2}{|l|}{ Moderate Changes } \\
\hline First Writing & Final Writing \\
\hline $\begin{array}{l}\text { Last month, my roommate had been } \\
\text { bullied by one person. That changed my } \\
\text { friend personality and he becomes } \\
\text { scared to walk alone, lack of confidence } \\
\text { and he seldom comes to school earlier. } \\
\text { His result has been decreased. }\end{array}$ & $\begin{array}{l}\text { I have a friend who is often bullied and his } \\
\text { name is Afiq. He is always alone during our } \\
\text { break. He is a petite boy and he always wears } \\
\text { dirty clothes. He comes from a poor family. His } \\
\text { mother is always sick and he needs money to } \\
\text { pay his mother medication. His father } \\
\text { disappeared when he was } 11 \text { years old. For } \\
\text { now, he needs to support his family by } \\
\text { working at a restaurant close to his house. }\end{array}$ \\
\hline $\begin{array}{l}\text { One day, I saw Anis who was bullied by } \\
\text { the seniors. But on the day. She confess } \\
\text { all about her problem to me. So, I need } \\
\text { to help her to settle her problem. If she } \\
\text { did not give them her money, the } \\
\text { seniors will punch her. }\end{array}$ & $\begin{array}{l}\text { Firstly, her name was Alia. She was a new } \\
\text { student in my and she was my classmate. } \\
\text { From my point of view, she was short and she } \\
\text { had dark skin. She was smelly and dirty. She } \\
\text { came from a poor family. She had a family } \\
\text { problem in her life. Her father was a drunkard } \\
\text { and her mother died. She was very smart and } \\
\text { clever. She always got a good result but she } \\
\text { was need and shy. }\end{array}$ \\
\hline $\begin{array}{l}\text { In conclusion, we have to report to } \\
\text { teacher if we are bullied in our school or } \\
\text { we will be in trouble. We should not be } \\
\text { a coward person in the school and even } \\
\text { if they are strong we will win. }\end{array}$ & $\begin{array}{l}\text { In conclusion, all parents out there must be } \\
\text { alert about their children condition. They must } \\
\text { teach their children to be brave so that their } \\
\text { children will be underestimated by others. } \\
\text { Furthermore, the society also have to report } \\
\text { any bully cases if they see someone is bullied. } \\
\text { We should not be a coward and weak. }\end{array}$ \\
\hline $\begin{array}{l}\text { Conclusion: } \\
\text { When we reached his home, I shared } \\
\text { the story of the incident with his } \\
\text { parents. This is crucial because parents } \\
\text { play important role to solve this } \\
\text { problem. His parents would } \\
\text { communicate with him. }\end{array}$ & $\begin{array}{l}\text { Conclusion: } \\
\text { I hope she can make more friend and I also } \\
\text { hope that we can always be as good as we are } \\
\text { now. Bullying has many reasons that we } \\
\text { should pay attention to. If someone sees a } \\
\text { bullying incident, it is necessary to report to } \\
\text { the police. It is also important for parents to } \\
\text { pay attention to their children's condition at } \\
\text { school to avoid them from bullying. }\end{array}$ \\
\hline
\end{tabular}

\section{Organisation}

Table 3 shows few extracts of paragraph 2 and 3 from some participants' first and final writing task: 
Table 3. Paragraph 2 and 3 Extracts Comparison.

\begin{tabular}{|c|c|}
\hline \multicolumn{2}{|l|}{ Significant Changes } \\
\hline First Writing & Final Writing \\
\hline $\begin{array}{l}\text { Last month my roommate was bullied } \\
\text { by one person. That changed my } \\
\text { friend's personality to become scared } \\
\text { all the time. He was not confident. - } \\
\text { Paragraph 2(last) }\end{array}$ & $\begin{array}{l}\text { "I have a friend who was often bullied. His } \\
\text { name was Afiq. He was always alone during } \\
\text { recess time. He was a petite boy and he always } \\
\text { wore dirty clothes. He came from a poor family. } \\
\text { His mother was always sick and he needed } \\
\text { money to pay for his mother medicines. His } \\
\text { father..." Paragraph 2, Participant } 3\end{array}$ \\
\hline $\begin{array}{l}\text { The next day, I went to school. During } \\
\text { recess time, I saw students at the } \\
\text { corner. They bullied a student, I ran to } \\
\text { there. - Paragraph } 2 \text { (last) }\end{array}$ & $\begin{array}{l}\text { "She is pretty good in academic. The physical } \\
\text { of her is beautiful. However, This was the } \\
\text { reason why Kelly was bullied. She was not } \\
\text { snobbish but she was always being attractive } \\
\text { for male students. Then, Kelly was bullied also } \\
\text { because she was from a poor family. She did } \\
\text { not have a beautiful beg and she did not } \\
\text { have...." - Paragraph 2, Participant } 9\end{array}$ \\
\hline $\begin{array}{l}\text { Last month, my friend Daniel was } \\
\text { bullied at the canteen after recess. My } \\
\text { friend was bullied by older students and } \\
\text { asked from my friend. - Paragraph } 2 \\
\text { (last) }\end{array}$ & $\begin{array}{l}\text { "Her name was Alice. She came from a poor } \\
\text { family. She was deaf and mute. She used the } \\
\text { hearing aid to communicate with friends. In her } \\
\text { school, she was a soft and lonely girl. She } \\
\text { always walked alone to the canteen and sat } \\
\text { alone. When she was in the class.."- Paragraph } \\
\text { 2, Participant } 7\end{array}$ \\
\hline $\begin{array}{l}\text { This participant did not write about } \\
\text { the details of their friend. }\end{array}$ & $\begin{array}{l}\text { "I still remember when I was in school, there } \\
\text { was a girl named Alice. She was a deaf and } \\
\text { mute girl, so she needs to use the hearing aid } \\
\text { to help here. That was my first time I saw a less- } \\
\text { able girl in school. According to the teacher, she } \\
\text { came from a poor family and her house was far } \\
\text { away from school. Alice was a soft girl because } \\
\text {...." - Paragraph 2, Participant } 8\end{array}$ \\
\hline $\begin{array}{l}\text { After the incident, I quickly went to Irfan } \\
\text { and helped him I saw his face was full } \\
\text { with blood. The water that he bought } \\
\text { was poured on the floor. I took the } \\
\text { towel in the toilet and cleaned up the } \\
\text { blood. - Paragraph } 3\end{array}$ & $\begin{array}{l}\text { "As his friend, I always saw Irfan was bullied by } \\
\text { a group of boys. When Irfan went to the toilet, } \\
\text { a group of boys would pour a gallon of dirty } \\
\text { water onto his school uniform and they also } \\
\text { locked Irfan in the toilet. Irfan could not } \\
\text { manage to go for the recess. So, Irfan did not } \\
\text { use his pocket money to buy some foods in the } \\
\text { canteen. After school hours, a group of boy }\end{array}$ \\
\hline
\end{tabular}




\begin{tabular}{|c|c|}
\hline & $\begin{array}{l}\text { who bullied Irfan would take his pocket money. } \\
\text { Irfan went back home without food and } \\
\text { starving." - Paragraph 3, Participant } 17\end{array}$ \\
\hline No paragraph 3 & $\begin{array}{l}\text { "Firstly, he is often bullied because of he has a } \\
\text { small body. His name is Farhan. He was the } \\
\text { new student but often praised by the teachers. } \\
\text { The bullies are..."- Paragraph 2, Participant } 4\end{array}$ \\
\hline $\begin{array}{l}\text { Without wasting anytime, I walked } \\
\text { toward him.- Paragraph } 3 \text { (last) }\end{array}$ & $\begin{array}{l}\text { "One day I was on my way back home from } \\
\text { school. I saw Chong was hit by a group of } \\
\text { gangsters in the school toilet. I was shocked but } \\
\text { I was afraid of them too. I ran quickly I felt } \\
\text { regret because..." - Paragraph 3, Participant } 19\end{array}$ \\
\hline No paragraph 3 & $\begin{array}{l}\text { "As one of her classmates, I saw her was being } \\
\text { bullied by a group mean girls. The girls were the } \\
\text { seniors in our school. When she went to the } \\
\text { toilet, they poured a gallon of dirty water on } \\
\text { her. Everyday, after school, she had to give all } \\
\text { of her pocket money to the bullies because if } \\
\text { she did not give it to them, they would hit her. } \\
\text { After all.."- Paragraph3, Participant } 16\end{array}$ \\
\hline No paragraph 3 & $\begin{array}{l}\text { "One day, I walked to the canteen, I saw a } \\
\text { group of seniors follow Jason from behind. I } \\
\text { kept following them silently and hid behind a } \\
\text { small tree. They asked him for his mone and } \\
\text { when Jason did not give the money, they would } \\
\text { punch him. So, he had to give his money to the } \\
\text { seniors. I felt.." - Paragraph 3, Participant } 15 \text {. }\end{array}$ \\
\hline No paragraph 3 & $\begin{array}{l}\text { "However, a gang of girls were jealous of Kelly. } \\
\text { They were all known for their bullying } \\
\text { behaviour at school. They already set a plan to } \\
\text { bully Kelly. The girls spread the story about } \\
\text { Kelly and her poor family in the internet. They } \\
\text { had humiliated her in public. Besides that, they } \\
\text { threw food to Kelly..." Paragraph 3, Participant } \\
6\end{array}$ \\
\hline
\end{tabular}

\section{Discussion}

The finding revealed that collaborative writing strategies improved learners' ability to elaborate the ideas and contents of their topic. Lo \& Hyland (2007) also found out in their studies that when learners are engaged to their writing task, they will be able to write more words. Learners are able to generate ideas and contents and also state clearly the main ideas 
of each paragraph. According to Islam \& Maab (2012), his finding on improving learners' in writing descriptive text through collaborative showed that mean score for content development of students' writing test improved from 61.43 (pre-test) to 77.86 (posttest). The finding from Islam \& Maab (2012) also supported the finding of this study where all 20 participants managed to develop interesting ideas and contents for their last writing and it helped them to increase number of words in their essay. Furthermore, the finding of this also showed that learners were able to elaborate their ideas without repeating unnecessary ideas. A study by Khatib \& Hussein (2015) also revealed that the experimental group exhibited higher total mean for content development compared to the control group during their post-writing post. Khatib \& Hussin (2015) cited Hirvela (2011) stated that collaborative writing strategies promote learners to learn from their peers and also knowledge of content. Wigglesworth et al. (2014) also conducted a study on collaborative writing and the finding from the interview with the students revealed working collaboratively allows them to fully be able to express their thoughts and point of view, be creative and develop new ideas.

Bringing in collaborative writing strategies in the classroom give the participants the room to learn to organise and paragraph their ideas appropriately. According to Islam et al., (2016), one of the problems in writing is writing needs the writers to be organised. So, learners have to be able to write out their ideas systematically. Islam et al., (2016) explains when learners acquire those skills to write, they will have high motivation to be active in their writing activities. So, the data of this study showed participants were able to organise their writing appropriately as they could sort their contents accordingly and they did not write different main ideas in the same paragraph. Furthermore, the finding of this study also showed that learners divide the main ideas according to paragraphs. This allowed them to write more words as they knew every main idea needed supporting details and examples and each paragraph should have only one or two main ideas. A study on the effect of collaborative writing done by Khatib \& Hussin (2015) explained the effect of collaborative writing on learners' organisation as the mean score of the experimental group showed progression of 13.73 to 17 . It is also mentioned by Khatib \& Hussin (2015) peer interaction in collaborative writing helps learners to be open to consider changing their content and organising manner if necessary. This is also supported by Shehadeh (2011) as he lists out one of the main contributions of collaborative writing to low proficient learners is on organisation of their essays and development of contents as this is in response to the survey data of their study. In his study Shehadeh (2011) students responded that the benefits of collaborative writing are beyond grammatical accuracy, but it also affects their ability to generate and elaborate ideas and put their ideas in an appropriate manner. When learners can solve their complex problem in writing such organisation, it will create an affective writing atmosphere and that is what collaborative strategies do.

\section{Conclusion}

The finding of this study resonated the effect of collaborative writing on two elements of writing fluency which are contents elaboration and organisation in essays among secondary school learners. In fact, the implementation of collaborative writing strategies helped them to improve their writing fluency and it is good if teachers can implement this feasible and engaging writing strategies which can help learners to improve their writing fluency before focusing on mechanical parts of writing as according to lie and melor (2018) learning starts 
with engagement. Collaborative writing strategies will also benefit low proficient learners as they develop their writing skills by getting help and scaffolding from their more capable peers and this might be able to reduce their writing anxiety and enhance their writing motivation. So, teachers indeed need to utilise collaborative writing as one of the feasible tools to help learners to improve their writing quality.

\section{References}

Al Ajmi, A. A. S., \& Ali, H. I. H. (2014). Collaborative Writing in Group Assignments in an EFL/ESL Classroom. English Linguistics Research, 3(2), 1-17. https://doi.org/10.5430/elr.v3n2p1

Aminloo, M. S. (2013). The Effect of Collaborative Writing on EFL Learners Writing Ability at Elementary Level. Journal of Language Teaching and Research, 4(4), 801-806. https://doi.org/10.4304/jltr.4.4.801-806

Atasoy, A., \& Temizkan, M. (2016). Evaluation of Secondary School Students' Writing Fluency Skills *. 1457-1484. https://doi.org/10.12738/estp.2016.5.0353

Fellner, T., Apple, M., Faculty, L., \& Dormer, R. (2006). 'Fluency' in L2 Writing : A Literature Review. 28(2), 97-134.

Fong, L. S. (2012). Students in the Production of Reports. 4, 396-407.

Ghufron, M. A. (2018). A COLLABORATIVE WRITING TECHNIQUE TO IMPROVE STUDENTS' SKILL IN WRITING ARGUMENTATIVE ESSAY (A Classroom Action Research at the Fourth Semeseter Students of English Education Depart ... (February).

Ghufron, M. A., \& Hawa, M. (2018). Teaching Writing of Argumentative Essay Using Collaborative Writing Technique Viewed from Students' Creativity: an Experimental TEACHING WRITING OF ARGUMENTATIVE ESSAY USING COLLABORATIVE WRITING TECHNIQUE VIEWED FROM STUDENTS ' CREATIVITY : AN EXPERIME. (February).

len, L. K., Yunus, M. M., \& Embi, M. A. (2018). Build Me Up: Overcoming Writing Problems Among Pupils in A Rural Primary School In Belaga, Sarawak, Malaysia. Jurnal Pendidikan Humaniora, 5(1), 1-7. https://doi.org/10.17977/um030v5i12017p001

Islam, U., \& Maab, K. (2012). IMPROVING THE STUDENTS ' ABILTY IN WRITING DESCRIPTIVE. 2(2), 11-20.

Islam, U., Maab, K., Ghufron, M. A., Biria, R., Milena, A., Luna, R., ... Kyndt, E. (2016). The Correlation Between the Students' Writing Motivation and the Writing Ability. 4(1), 219237. https://doi.org/10.1080/00461520903433539

Ismail, N., Hussin, S., \& Darus, S. (2012). ESI tertiary students' writing problems and needs: Suggested elements for an additional online writing program (IQ-write) for the BEL 311 course. International Journal of Learning, 18(9), 69-80. https://doi.org/10.18848/14479494/CGP/v18i09/47748

Jalili, M. H., \& Shahrokhi, M. (2017). The effect of collaborative writing on Iranian EFL learners' L2 writing anxiety and attitudes. Journal of Applied Linguistics and Language Research, 4(2), 203-215. Retrieved from www.jallr.com/index.php/JALLR/article/download/538/pdf538

Khatib, M., \& Hussein, M. (2015). Languaging and Writing Skill: The Effect of Collaborative Writing on EFL Students' Writing Performance. 6(1).

https://doi.org/10.7575/aiac.alls.v.6n.1p.203

Khodabakhshzadeh, H., \& Samadi, F. (2017). The Effect of Collaborative Writing on Iranian EFL Learners' Task Achievement in Writing and Their Perception. International Journal of Applied Linguistics and English Literature, 7(1), 113. 
https://doi.org/10.7575/aiac.ijalel.v.7n.1p.113

Kwan, L. S. L., \& Yunus, M. M. (2015). Group participation and interaction in ESL wiki collaborative writing among Malaysian gifted students. Asian Social Science, 11(2), 5968. https://doi.org/10.5539/ass.v11n2p59

Kwon, C. (2014). Student Perspectives on Group Work and Use of L1: Academic Writing in a University Efl Course in Thailand. Second Language Studies, 33(1), 85-124.

Lo, J., \& Hyland, F. (2007). Enhancing students' engagement and motivation in writing: The case of primary students in Hong Kong. Journal of Second Language Writing, 16(4), 219237. https://doi.org/10.1016/j.jslw.2007.06.002

Marshan, S. (2016). USING COLLABORATIVE WRITING IN TEACHING WRITING Sukirman. 2(1), $33-46$.

Pae, J.-K. (2011). Collaborative Writing versus Individual Writing: Fluency, Accuracy, Complexity, and Essay Score. 14(1), 121-148. Retrieved from http://kmjournal.bada.cc/wp-content/uploads/2013/05/14-1-5Pae.pdf

Roselli, N. D. (2016). Collaborative learning: Theoretical foundations and applicable strategies to university. Propositos Y Representaciones, 4(1), 251-280.

https://doi.org/10.20511/pyr2016.v4n1.90Azman, M. N. Bin, \& Ayub, M. K. Bin. (2021). Collaborative Writing Strategies: The Effects on Malaysia Secondary School Learners' Writing Fluency. International Journal of Academic Research in Progressive Education and Development, 10(2), 1023-1030.

Shehadeh, A. (2011). Effects and student perceptions of collaborative writing in L2. 20, 286305. https://doi.org/10.1016/j.jslw.2011.05.010

Stell, A. (2018). Exploring the use of collaborative writing in an EFL classroom context. 4712(32), 63-97.

Zhang, M. (2018). Collaborative writing in the EFL classroom: The effects of L1 and L2 use. System, 76, 1-12. https://doi.org/10.1016/j.system.2018.04.009 